Aspirasi: Jurnal Masalah-Masalah Sosial | Volume 9, No, 2 Desember 2018

ISSN: 2086-6305 (print) ISSN: 2614-5863 (electronic)

DOI: https://doi.org/10.22212/aspirasi.v7il.1084

link online: http://jurnal.dpr.go.id/index.php/aspirasi/index

\title{
IMPLEMENTASI KEBIJAKAN PENGEMBANGAN PARIWISATA BERKELANJUTAN DI KARIMUNJAWA
}

\author{
Implementation of Sustainable Tourism Development Policies in Karimunjawa
}

\author{
Sri Nurhayati Qodriyatun \\ sri.qodriyatun@dpr.go.id \\ Pusat Penelitian Badan Keahlian DPR RI \\ Jl. Gatot Subroto Senayan Jakarta
}

Naskah Diterima: 29 September 2018 | Naskah direvisi: 4 Desember 2018 | Naskah diterbitkan: 31 Desember 2018

\begin{abstract}
Tourism has been the backbone of Indonesia's economy in the last three years. Contribution of tourism to national GDP is expected to increase to $15 \%$ by 2019. Those target is encouraging the development of tourism in many tourist potential areas, such as Karimunjawa. Karimunjawa is an area of 27 small islands including 22 protected islands within the area (Karimunjawa National Park). The Government has made policies in the development of tourism on small islands. The problem is on the implementation of those policy in Karimunjawa from the point of view of policy maker, policy implementer, and target group (Karimunjawa community). The result of a qualitative research conducted in 2018 on tourism development in Karimunjawa showed that tourism development in Karimunjawa has not been sustainable. Even though it has opened up new jobs and added income to the community, there has been changes of community's values and environmental damage on some spot areas. There is a need for an integrated plan that involves many sectors and stakeholders. The plan includes spatial planning, calculation of its carrying capacity (ecological, physical, and social), analysis or study on environmental impact, utilization of natural resources in an environmentally friendly manner, and roles and responsibilities of each stakeholder involved in tourism development. There is also a need for visitor quota based on the calculation of carrying capacity as well as additional attractions to increase the length of tourist visits.
\end{abstract}

Keywords: policy implementation, sustainable tourism, small islands, protected area, integrated planning

Abstrak: Pariwisata telah menjadi backbone perekonomian Indonesia dalam tiga tahun terakhir. Pemerintah menargetkan kontribusi sektor pariwisata terhadap PDB nasional meningkat menjadi $15 \%$ pada tahun 2019. Target tersebut mendorong dikembangkannya pariwisata di daerahdaerah yang memiliki potensi pariwisata, seperti Karimunjawa. Karimunjawa merupakan daerah kepulauan dengan 27 pulau kecil di dalamnya dengan 22 pulau di antaranya berada dalam kawasan konservasi (Taman Nasional Karimunjawa). Pemerintah telah menyusun kebijakan untuk pengembangan pariwisata di pulau-pulau kecil agar berkelanjutan. Permasalahannya adalah bagaimana implementasi kebijakan tersebut dalam pengembangan pariwisata di Karimunjawa dilihat dari sudut pandang penyusun kebijakan, pelaksana kebijakan, dan target group (masyarakat Karimunjawa). Penelitian kualitatif yang dilakukan pada tahun 2018 terhadap pengembangan pariwisata di Karimunjawa memperlihatkan bahwa pengembangan pariwisata di Karimunjawa belum berkelanjutan. Karena meskipun secara ekonomi telah membuka lapangan kerja baru dan menambah penghasilan di masyarakat, namun secara sosial telah terjadi perubahan nilai dalam masyarakat dan secara ekologis telah terjadi kerusakan lingkungan. Perlu ada satu perencanaan 
yang terintegrasi yang melibatkan berbagai sektor dan stakeholders. Perencanaan tersebut memuat penataan ruangnya, perhitungan daya dukungnya (daya dukung ekologis, daya dukung fisik, dan daya dukung sosial), studi AMDAL atau UKL/UPL nya, pemanfaatan sumber daya alam secara ramah lingkungan, serta peran dan tanggung jawab dari setiap stakeholders yang terlibat dalam pengembangan pariwisata. Selain itu, perlu ada penetapan kuota pengunjung didasarkan perhitungan daya dukung dan menambah atraksi untuk meningkatkan lama kunjungan wisata.

Kata kunci: implementasi kebijakan, pariwisata berkelanjutan, pulau-pulau kecil, kawasan konservasi, perencanaan terintegrasi

\section{Pendahuluan}

Pariwisata adalah salah satu potensi yang kini banyak digali dan dikembangkan di banyak negara. Ada peningkatan kecenderungan pasar pariwisata internasional untuk berwisata di kawasan yang masih alami. Kecenderungan ini memberi peluang bagi pengembangan pariwisata Indonesia karena Indonesia merupakan negara kepulauan terbesar di dunia yang kaya akan keanekaragaman hayati, memiliki panjang garis pantai lebih dari $81.000 \mathrm{~km}$ dan 17.504 pulau, di mana 10.000 pulau di antaranya merupakan pulau-pulau kecil, bahkan sangat kecil, belum bernama dan tidak berpenghuni. Pulau-pulau kecil memiliki potensi dimanfaatkan untuk kegiatan pariwisata dalam bentuk wisata bahari (marine tourism) ataupun ekowisata (ecotourism).

Wisata bahari merupakan satu bentuk wisata alam yang menawarkan keindahan dan kenyamanan alami dari kombinasi sinar matahari, laut, dan pantai berpasir yang bersih (3S - sun, sea, and sand) (Nurifdinsyah \& Pakpahan dalam Supriyanto, 2003; 11-17). Sedangkan ekowisata merupakan perjalanan wisata alam yang bertanggung jawab dengan cara mengkonservasi lingkungan dan meningkatkan kesejahteraan masyarakat lokal (Garrod \& Wilson, 2003). Dalam portofolio produk wisata Indonesia, wisata alam menempati posisi kedua setelah wisata budaya, di mana dalam wisata alam ini ada wisata bahari, ekowisata, dan wisata petualangan (Tabel 1).

Pariwisata di Indonesia tumbuh dengan pesat dalam beberapa tahun terakhir. Dalam tiga tahun terakhir sumbangan pariwisata terhadap devisa negara terus meningkat dan bahkan melampaui yang ditargetkan pemerintah. Di tahun 2015, target devisa dari pariwisata adalah Rp.144 triliun dan tercapai Rp.175.71 triliun (capaian 122,02\% dari target). Demikian juga di tahun 2016 dan 2017 capaian devisa dari pariwisata melebihi yang ditargetkan pemerintah. Pariwisata juga berkontribusi terhadap PDB (Produk Domestik Bruto) nasional. Jika di tahun 2015 sumbangan pariwisata terhadap PDB nasional sebesar $4,25 \%$, maka di tahun 2017 meningkat menjadi 5\%. Selain itu, pariwisata juga memberi sumbangan

Tabel 1. Portofolio Pasar/Customer dan Portofolio Produk Wisata Indonesia

\begin{tabular}{|c|c|c|}
\hline $\begin{array}{l}\text { Portofolio } \\
\text { Pelanggan }\end{array}$ & Personal & Wisnus Individu/Family Traveler, Komunitas \\
\hline \multirow[t]{9}{*}{ Portofolio Produk } & Alam (Nature) $(35 \%)$ & Wisata Bahari (35\%) \\
\hline & & 2. Ekowisata $(45 \%)$ \\
\hline & & 3. Wisata petualangan $(20 \%)$ \\
\hline & Budaya (Culture) $(60 \%)$ & Wisata warisan budaya dan sejarah (20\%) \\
\hline & & Wisata belanja dan kuliner (45\%) \\
\hline & & Wisata kota dan desa $(35 \%)$ \\
\hline & Buatan manusia (5\%) & Wisata mice $(25 \%)$ \\
\hline & & Wisata olahraga $(60 \%)$ \\
\hline & & Objek wisata terintegrasi $(15 \%)$ \\
\hline
\end{tabular}

Sumber: Ratman, FGD 9 Februari 2018. 
terhadap penyerapan tenaga kerja, baik tenaga kerja langsung, tidak langsung, ataupun ikutan dari kegiatan pariwisata. Setiap tahun terjadi peningkatan penyerapan tenaga kerja di sektor pariwisata. Di tahun 2015 tenaga kerja yang terserap di sektor pariwisata mencapai 10,36 juta orang, tahun 2016 mencapai 12,28 juta orang dan tahun 2017 mencapai 12 juta orang (lihat Tabel 2).

Tabel 2. Perbandingan Penerimaan Devisa, Sumbangan Terhadap PDB Nasional, dan Penyerapan Tenaga Kerja dari Sektor Pariwisata pada Tahun 2015 - 2017

\begin{tabular}{|c|c|c|c|}
\hline Tahun & 2015 & 2016 & 2017 \\
\hline \multicolumn{4}{|l|}{$\begin{array}{l}\text { Penerimaan } \\
\text { Devisa }\end{array}$} \\
\hline $\begin{array}{l}\text { Target (triliun } \\
\text { Rp) }\end{array}$ & 144 & 172 & 200 \\
\hline $\begin{array}{l}\text { Capaian (triliun } \\
\text { Rp) }\end{array}$ & $\begin{array}{l}175,71 \\
(122,02 \%)\end{array}$ & $\begin{array}{l}176,23 \\
(102,46 \%)\end{array}$ & $\begin{array}{l}204,04 \\
(112,66 \%)\end{array}$ \\
\hline \multicolumn{4}{|l|}{$\begin{array}{l}\text { Sumbangan } \\
\text { terhadap PDB }\end{array}$} \\
\hline $\begin{array}{l}\text { Target ( } \% \text { dari } \\
\text { PDB nasional) }\end{array}$ & 4,23 & 4,5 & 5,25 \\
\hline $\begin{array}{l}\text { Capaian (\% dari } \\
\text { PDB nasional) }\end{array}$ & $\begin{array}{l}4,25 \\
(106 \%)\end{array}$ & $\begin{array}{l}4,13 \\
(82,6 \%)\end{array}$ & $\begin{array}{l}5 \\
(83,33 \%)\end{array}$ \\
\hline \multicolumn{4}{|l|}{$\begin{array}{l}\text { Jumlah tenaga } \\
\text { kerja langsung, } \\
\text { tidak langsung, } \\
\text { dan ikutan sektor } \\
\text { pariwisata }\end{array}$} \\
\hline $\begin{array}{l}\text { Target (juta } \\
\text { orang) }\end{array}$ & 11,4 & 11,8 & 12,4 \\
\hline $\begin{array}{l}\text { Capaian (juta } \\
\text { orang) }\end{array}$ & $\begin{array}{l}10,36 \\
(91,68 \%) \\
\end{array}$ & $\begin{array}{l}12,28 \\
(108,6 \%)\end{array}$ & $\begin{array}{l}12 \\
(96,77 \%) \\
\end{array}$ \\
\hline
\end{tabular}

Sumber: Kementerian Pariwisata, 2018, diolah.

Indonesia memiliki potensi untuk pengembangan pariwisata dan hal itu disadari betul oleh pemerintahan Joko Widodo. Oleh karena itu, Pemerintah Joko Widodo di tahun 2019 menargetkan sektor pariwisata harus memberikan kontribusi terhadap PDB nasional sebesar 15 $\%$ (saat ini masih 9-10\%). Sedangkan devisa dari sektor pariwisata ditargetkan meningkat dari Rp.140 triliun - Rp.150 triliun menjadi Rp.280 triliun pada 2019. Kontribusi sektor pariwisata terhadap kesempatan kerja ditargetkan meningkat dari 11 juta - 12 juta menjadi 13 juta pada 2019. Pemerintah juga menargetkan indeks daya saing pariwisata dalam Travel and Tourism Competitiveness Index (TTCI) World Economic Forum (WEF) meningkat dari peringkat ke-42 saat ini menjadi ke-30 pada tahun 2019. Di sisi lain jumlah kedatangan wisata mancanegara (wisman) ditargetkan meningkat dari 10 juta 15 juta saat ini menjadi 20 juta pada tahun 2019. Adapun jumlah perjalanan wisatawan nusantara (wisnus) ditargetkan meningkat dari 250 juta - 260 juta menjadi 275 juta pada tahun $2019 .{ }^{1}$ Target tersebut semakin memacu banyak daerah untuk mengembangkan pariwisata, termasuk pariwisata di pulau-pulau kecil.

Karimunjawa merupakan daerah kepulauan di Provinsi Jawa Tengah yang juga dikembangkan menjadi daerah destinasi wisata. Kawasan yang merupakan kawasan konservasi dalam bentuk Taman Nasional Karimunjawa, menghadapi berbagai tekanan ekologis seiring dengan semakin pesatnya pembangunan wisata dan meningkatnya pertumbuhan penduduk di wilayah tersebut. Pengembangan pariwisata di Karimunjawa menurut penelitian Limbong dan Soetomo (2014) telah mengakibatkan terjadinya perubahan zonasi Taman Nasional Karimunjawa sebanyak 3 kali sejak pertama ditetapkan sebagai kawasan konservasi. Perubahan zonasi yang terjadi dinilai akan mengancam keberlangsungan ekologi kawasan Taman Nasional Karimunjawa, karena luasan zona pemanfaatan untuk pariwisata tidak sebanding dengan kawasan zona inti dan zona perlindungan. Ada 7 lokasi yang semula merupakan zona perlindungan berubah menjadi zona pemanfaatan. Selain itu pembangunan akomodasi penginapan baru yang terus bertambah mengurangi lahan terbuka di kepulauan Karimunjawa, dan itu berdampak terhadap ketersediaan air di kepulauan Karimunjawa. Kegiatan snorkelling juga meningkat seiring dengan terus bertambahnya wisatawan yang datang ke Karimunjawa. Minimnya pengetahuan pengunjung dan kurangnya pengawasan terhadap kegiatan tersebut telah berdampak terhadap semakin luasnya kawasan terumbu karang yang rusak.

Kemenpar Targetkan Kontribusi $15 \%$ pada 2019, Tri Listiyarini, Minggu 10 September 2017, http:// id.beritasatu.com/home/kemenpar-targetkan-kontribusi-15pada-2019/165070, diakses 2 April 2018. 
Sebenarnya Kementerian Pariwisata telah mengeluarkan kebijakan tersendiri dalam pengembangan pariwisata di pulau-pulau kecil, yaitu melalui Peraturan Menteri Kebudayaan dan Pariwisata Nomor: KM.67/UM.001/MKP/2004 tentang Pedoman Umum Pengembangan Pariwisata di Pulau-Pulau Kecil. Kebijakan tersebut dilatarbelakangi oleh adanya kondisi daya dukung pulau-pulau kecil yang terbatas. Seperti disebutkan dalam UU No. 27 Tahun 2007 tentang Pengelolaan Wilayah Pesisir dan Pulaupulau kecil (yang sudah diperbaharui dengan UU No. 1 Tahun 2014) bahwa pulau kecil itu memiliki karakteristik: (a) terpisah dari pulau besar; (b) sangat rentan terhadap perubahan yang disebabkan manusia; (c) memiliki keterbatasan daya dukung pulau; (d) apabila berpenghuni penduduknya mempunyai kondisi sosial dan budaya yang khas; dan (e) memiliki ketergantungan ekonomi lokal pada perkembangan ekonomi luar pulau, baik induk maupun kontinen. Dengan mengacu pada kebijakan tersebut, pengembangan pariwisata di pulau-pulau kecil diharapkan dapat berkelanjutan.

Namun pengembangan wilayah pesisir dan pulau-pulau kecil juga mengacu pada kebijakan dari Kementerian Kelautan dan Perikanan, yaitu melalui UU No. 27 Tahun 2007 tentang Pengelolaan Wilayah Pesisir dan Pulau-Pulau Kecil (yang telah diperbarui dengan UU No. 1 Tahun 2014 tentang Perubahan Atas UndangUndang Nomor 27 tentang Pengelolaan Wilayah Pesisir dan Pulau-Pulau Kecil). UU tersebut menyatakan bahwa pengelolaan pesisir dan pulau-pulau kecil harus didasarkan perencanaan (Rencana Strategis Wilayah Pesisir dan PulauPulau Kecil (RSWP-3-K), Rencana Zonasi Wilayah Pesisir dan Pulau-Pulau Kecil (RZWP3-K), Rencana Pengelolaan Wilayah Pesisir dan Pulau-Pulau Kecil (RPWP-3-K), dan Rencana Aksi Pengelolaan Wilayah Pesisir dan PulauPulau Kecil (RAPWP-3-K)). Belum semua daerah menyusun perencanaan tersebut. Di sisi lain, Karimunjawa yang juga merupakan kawasan konservasi, yang dalam pengelolaannya mengacu pada kebijakan dari Kementerian Lingkungan Hidup dan Kehutanan terkait pengelolaan kawasan konservasi (UU No. 5
Tahun 1990 tentang Konservasi Sumber Daya Alam Hayati dan Ekosistemnya dan beberapa peraturan pelaksananya)

Berdasarkan latar belakang tersebut maka permasalahan yang diangkat adalah bagaimana implementasi kebijakan pengembangan pariwisata di pulau-pulau kecil agar tetap berkelanjutan dengan berbagai kebijakan yang ada tersebut di atas. Implementasi kebijakan akan dilihat dari sudut pandang pembuat kebijakan, pejabat-pejabat pelaksana kebijakan dan instansi pelaksana di lapangan, serta dari sudut pandang target group (masyarakat yang menjadi sasaran kebijakan yaitu masyarakat di daerah pulau-pulau kecil). Oleh karena itu, pertanyaan penelitiannya adalah bagaimana implementasi kebijakan pengembangan pariwisata di Karimunjawa dari sudut pandang pembuat kebijakan, pelaksana kebijakan, dan dari sudut pandang masyarakat Karimunjawa. Sudahkah pariwisata yang dikembangkan di Karimunjawa berkelanjutan dengan mengacu pada konsep sustainable tourism.

Penelitian ini ditujukan untuk mengetahui bagaimana implementasi kebijakan pengembangan pariwisata di pulau-pulau kecil dari sudut pandang pembuat kebijakan, pelaksana kebijakan, dan masyarakat target di mana pariwisata tersebut dikembangkan. Hasil penelitian diharapkan dapat memberi manfaat secara praktis, memberikan masukan untuk DPR RI khususnya Komisi X (yang membidangi pariwisata) dan Komisi IV (yang membidangi pembangunan di pulau-pulau kecil dan pembangunan di kawasan konservasi). Berbagai informasi yang didapat dari penelitian dapat dijadikan bahan masukan bagi DPR (Komisi $\mathrm{X}$ dan Komisi IV) dalam melaksanakan fungsi legislasi, anggaran, dan pengawasan. Penelitian ini diharapkan juga memberi manfaat secara akademis, yaitu dapat memberikan sumbangan bagi pengembangan ilmu pengetahuan khususnya di bidang kebijakan lingkungan dan kebijakan sosial terkait pengembangan pariwisata dan peningkatan kesejahteraan masyarakat di pulaupulau kecil.

Penelitian dilakukan di tahun 2018 dengan menggunakan metode penelitian kualitatif. 
Adapun teknik pengumpulan data dilakukan melalui observasi (pengamatan), wawancara (interview), dan studi dokumen (Emzir, 2016: 37-62). Observasi yang digunakan adalah observasi non-partisipan, yaitu observasi yang menjadikan peneliti sebagai penonton atau penyaksi terhadap gejala atau kejadian yang menjadi topik penelitian (Emzir, 2016: 40). Dalam hal ini peneliti melakukan observasi terhadap sarana dan prasarana pariwisata yang telah dikembangkan di Karimunjawa dalam rangka menunjang pengembangan pariwisata berkelanjutan. Sedangkan teknik wawancara yang digunakan adalah wawancara tertutup terbuka. Teknik wawancara ini merupakan gabungan teknik wawancara tertutup dengan mengajukan pertanyaan-pertanyaan yang menuntut jawabanjawaban tertentu, dan teknik wawancara terbuka yang dilakukan dengan mengajukan pertanyaanpertanyaan yang tidak dibatasi jawabannya (Emzir, 2016:51). Melalui wawancara peneliti menggali pendapat dari pembuat kebijakan, pelaksana kebijakan di lapangan, dan masyarakat Karimunjawa sebagai target group dari kebijakan pengembangan pariwisata berkelanjutan di pulau-pulau kecil. Sedangkan studi dokumen digunakan untuk mendukung tambahan pemahaman bagi peneliti atas hasil wawancara dan observasi. Dokumen yang dikumpulkan berupa dokumen tentang rencana pengembangan pariwisata Karimunjawa dan dokumen zonasi Taman Nasional Karimunjawa.

Sampel penelitiannya kecil, yang telah ditentukan terlebih dahulu (purposive) dan dilakukan dengan sistem snowball (Sugiyono, 2017:27-29). Adapun sampel penelitiannya adalah pembuat kebijakan (Asdep Pengembangan Wisata Alam dan Buatan Kementerian Pariwisata, Direktur Pendayagunaan Pesisir dan Pulau-Pulau Kecil Kementerian Kelautan dan Perikanan, Dirjen Konservasi Sumber Daya Alam Hayati dan Ekosistem Kementerian Lingkungan Hidup dan Kehutanan), pelaksana kebijakan (Dinas Pemuda, Olahraga, dan Pariwisata Provinsi Jawa Tengah, Dinas Pariwisata dan Kebudayaan Kabupaten Jepara, Dinas Kelautan dan Perikanan Provinsi Jawa Tengah, Balai Taman Nasional
Karimunjawa) dan masyarakat kelompok target kebijakan dari pengembangan pariwisata yang berkelanjutan di pulau-pulau kecil (masyarakat di kepulauan Karimunjawa).

Tabel 3. Data yang Dikumpulkan Selama Penelitian

\begin{tabular}{|c|c|}
\hline Responden & Data \\
\hline $\begin{array}{l}\text { Penyusun kebijakan } \\
\text { (Asdep Pengembangan } \\
\text { Wisata Alam dan } \\
\text { Buatan Kementerian } \\
\text { Pariwisata, Direktur } \\
\text { Pendayagunaan Pesisir } \\
\text { dan Pulau-Pulau Kecil } \\
\text { Kementerian Kelautan } \\
\text { dan Perikanan, } \\
\text { Dirjen Konservasi } \\
\text { Sumber Daya Alam } \\
\text { Hayati dan Ekosistem } \\
\text { Kementerian } \\
\text { Lingkungan Hidup dan } \\
\text { Kehutanan) }\end{array}$ & $\begin{array}{l}\text { Kebijakan yang dibuat } \\
\text { untuk pengembangan } \\
\text { pariwisata di pulau-pulau } \\
\text { kecil } \\
\text { Tujuan yang ingin dicapai } \\
\text { dari kebijakan } \\
\text { - Implementasi di lapangan, } \\
\text { kendala dan upaya untuk } \\
\text { mengatasinya } \\
\text { Koordinasi dengan } \\
\text { kementerian lain atau } \\
\text { dengan pemerintah daerah } \\
\text { dalam implementasi } \\
\text { kebijakan } \\
\text { Ketercapaian tujuan } \\
\text { kebijakan (berhasil/tidak) } \\
\text { Jika tidak berhasil, apa } \\
\text { masalahnya } \\
\text { Jika berhasil, faktor } \\
\text { apa yang mendukung } \\
\text { keberhasilan }\end{array}$ \\
\hline $\begin{array}{l}\text { Pelaksana Kebijakan } \\
\text { (Dinas Pemuda, Olah } \\
\text { Raga, dan Pariwisata } \\
\text { Provinsi Jawa Tengah, } \\
\text { Dinas Pariwisata } \\
\text { dan Kebudayaan } \\
\text { Kabupaten Jepara, } \\
\text { Dinas Kelautan dan } \\
\text { Perikanan Provinsi } \\
\text { Jawa Tengah, Balai } \\
\text { Taman Nasional } \\
\text { Karimunjawa) }\end{array}$ & $\begin{array}{l}\text { Apa tindakan yang } \\
\text { dilakukan instansi/pejabat } \\
\text { untuk melaksanakan } \\
\text { kebijakan pengembangan } \\
\text { pariwisata di pulau-pulau } \\
\text { kecil (program, kegiatan, } \\
\text { regulasi, koordinasi, } \\
\text { penganggaran, penyiapan } \\
\text { SDM) } \\
\text { Kendala dan upaya untuk } \\
\text { mengatasi kendala }\end{array}$ \\
\hline $\begin{array}{l}\text { Target Group } \\
\text { (Masyarakat } \\
\text { Kepulauan } \\
\text { Karimunjawa) }\end{array}$ & $\begin{array}{l}\text { Dampak yang dirasakan } \\
\text { oleh masyarakat atas } \\
\text { kebijakan pengembangan } \\
\text { pariwisata di pulau-pulau } \\
\text { kecil (sosial budaya, } \\
\text { ekonomi, dan lingkungan) }\end{array}$ \\
\hline
\end{tabular}

Semua data yang terkumpul kemudian akan dianalisis menggunakan teknik analisis penelitian kualitatif menurut Miles dan Huberman, yaitu dengan melakukan reduksi data, penyajian data dan penarikan verifikasi/kesimpulan. Reduksi data merujuk pada proses pemilihan, pemusatan perhatian pada penyederhanaan, pengabstrakan, 
dan transformasi data "kasar" yang muncul dari catatan-catatan tertulis di lapangan, baik dari hasil wawancara, observasi, ataupun studi dokumentasi. Penyajian data adalah suatu kegiatan ketika sekumpulan informasi disusun, baik dalam bentuk teks naratif ataupun dalam berbagai jenis matrik, grafik, jaringan kerja, ataupun bagan. Semua dirancang untuk merakit informasi yang tersusun dalam suatu bentuk yang padu, bentuk yang praktis. Langkah terakhir yaitu penarikan verifikasi/kesimpulan, merupakan kegiatan memutuskan apa "makna" sesuatu dari kumpulan data tersebut (Emzir, 2016:129 - 135). Reduksi data, penyajian data, dan penarikan kesimpulan dilakukan dengan mengacu pada konsep pembangunan pariwisata berkelanjutan. Atau dengan kata lain, temuan lapangan terkait prinsip- prinsip pengembangan pariwisata di pulau-pulau kecil dan arah pengembangan pariwisata di pulau-pulau kecil kemudian dianalisis dengan menggunakan konsep pembangunan pariwisata berkelanjutan menurut WTO (dengan 3 pilarnya yaitu berkelanjutan secara ekonomi, sosial budaya, dan lingkungan). Dengan menggunakan konsep pembangunan pariwisata berkelanjutan tersebut akan dapat gambaran apakah implementasi dari kebijakan pengembangan pariwisata di pulau-pulau kecil sudah sesuai dengan konsep pembangunan pariwisata berkelanjutan. Jika belum, berdasarkan temuan lapangan akan dicari kendala dan faktor penghambat dari implementasi kebijakan pengembangan pariwisata berkelanjutan di pulau-pulau kecil.

\section{Pulau-Pulau Kecil}

Belum ada batasan yang tetap tentang pengertian pulau kecil baik di tingkat nasional maupun internasional, akan tetapi terdapat suatu kesepakatan umum bahwa yang dimaksud dengan pulau kecil adalah pulau yang berukuran kecil yang secara ekologis terpisah dari pulau induknya dan memiliki batas yang pasti, terisolasi dari habitat lain sehingga mempunyai sifat insular (Bengen, 2001). Menurut UU No. 27 Tahun 2007 tentang Pengelolaan Wilayah Pesisir dan Pulau-Pulau Kecil, pulau kecil didefinisikan sebagai pulau dengan luas lebih kecil atau sama dengan $2.000 \mathrm{~km} 2$.

Salm et.al dalam Bengen menyatakan bahwa pulau kecil dapat dikelompokkan menjadi dua, yaitu pulau oseanik dan pulau kontinental. Pulau oseanik dibedakan menjadi pulau vulkanik dan pulau koral/karang (Bengen sebagaimana dikutip Johan, 2011). Sebagian besar pulau kecil merupakan pulau oseanik yang memiliki karakteristik berbeda dengan pulau kontinental baik dari ukuran maupun stabilitas dan penggunaannya. Secara umum pulau kecil memiliki karakteristik biogeofisik yang menonjol, yaitu (Bengen, 2002):

1. Terpisah dari habitat pulau induk (mainland) sehingga bersifat insular;

2. Memiliki sumber daya air tawar yang terbatas baik air permukaan maupun air tanah, dengan daerah tangkapan airnya relatif kecil sehingga sebagian besar aliran air permukaan dan sedimen masuk ke laut;

3. Peka dan rentan terhadap pengaruh eksternal baik alami maupun akibat kegiatan manusia, seperti badai, gelombang besar, pencemaran;

4. Memiliki sejumlah jenis endemik yang bernilai ekologis tinggi;

5. Area perairannya lebih luas dari area daratannya dan relatif terisolasi dari daratan utamanya (benua atau pulau besar);

6. Tidak mempunyai hinterland yang jauh dari pantai.

Pulau kecil merupakan habitat yang terisolasi dengan habitat lain sehingga keterisolasian ini umumnya akan membentuk budaya yang berbeda dengan masyarakat pulau kontinen dan daratan (Dahuri, 1998). Kusumastanto membuat tiga kriteria yang dapat digunakan untuk membuat batasan suatu pulau kecil, yaitu batasan fisik atau luasan pulau, batasan ekologis (proporsi spesies endemik dan terisolasi), dan keunikan budaya (dalam Johan, 2011). Oleh karena itu, dalam pengembangan pulau kecil perlu kehatihatian dan perencanaan yang baik agar tidak menimbulkan dampak negatif bagi kehidupan masyarakat di pulau kecil tersebut. Termasuk ketika akan dikembangkan menjadi destinasi wisata. 


\section{Pariwisata Berkelanjutan (Sustainable Tourism)}

Dalam pengembangan pariwisata ada 4 komponen yang harus dipenuhi yaitu attractions, accessibilities, amenities, dan ancillary services (Cooper dkk, 2005, dalam Astuti dan Noor, 2016:26). Attractions (atraksi) adalah daya tarik yang ditawarkan dari suatu kawasan pariwisata, seperti keindahan alam, kebudayaan daerah, dan lain-lain. Accessibilities (aksesibilitas) merupakan akses transportasi yang tersedia menuju dan di dalam kawasan pariwisata, seperti adanya jalur penerbangan, kereta, bus, atau kapal menuju kawasan pariwisata. Selain itu di dalam kawasan juga tersedia moda transportasi yang dapat digunakan wisatawan untuk menuju objek wisata yang tersedia dalam kawasan pariwisata tersebut. Amenities (amenitas atau fasilitas) merupakan akomodasi yang tersedia di kawasan pariwisata seperti adanya tempat penginapan (hotel, homestay, hostel, dll), rumah makan, fasilitas kesehatan, tempat penjualan souvenir, tempat hiburan, tempat pengolahan sampah/ limbah, listrik, air bersih, dll. Ancillary services merupakan organisasi kepariwisataan yang dibutuhkan untuk pelayanan wisatawan, seperti asosiasi perhotelan, asosiasi pemandu wisata, asosiasi biro perjalanan, dll.

Dalam pengembangan pariwisata tersebut ada tiga bidang pokok yang dipengaruhi, yaitu kondisi ekonomi, sosial budaya, dan lingkungan hidup dari kawasan wisata. Harapannya pengembangan pariwisata akan berdampak positif tidak hanya terhadap pembangunan ekonomi (peningkatan pendapatan), tetapi juga terhadap kondisi sosial budaya (kesejahteraan masyarakat meningkat dengan kelestarian budaya tetap terjaga) dan kondisi lingkungan (kelestarian lingkungan terjaga). Untuk itulah pengembangan pariwisata yang berkelanjutan diperlukan.

Konsep pariwisata berkelanjutan (sustainable tourism) diadopsi dari konsep pembangunan berkelanjutan (sustainable development) yang pertama diperkenalkan oleh WCED (World Commission on Environment and Development) di Brundtland Report tahun 1987. The World Tourism Organization (UNWTO) dengan mengadopsi konsep tersebut mendefinisikan pariwisata berkelanjutan sebagai "form of tourism that are consistent with natural, social, and community values and which allow both host and guest to enjoy positive and worthwhile interaction and shared experience (bentuk pariwisata yang selaras dengan alam, dan nilai-nilai sosial budaya masyarakat, di mana antara kedua belah pihak yaitu tuan rumah dan tamu saling menikmati dan saling berbagi pengalaman baru di antara mereka) (Edington \& Smith sebagaimana dikutip Suwena, 2010: 279).

Adatigakomponen yang harus dipenuhi dalam pembangunan pariwisata berkelanjutan menurut Heillbronn (sebagaimana dikutip Tamaratika dan Rozyidie, 2017: 125-133), yaitu berkelanjutan secara lingkungan, berkelanjutan secara ekonomi, dan berkelanjutan secara sosial budaya. Berkelanjutan secara lingkungan dilakukan melalui pemanfaatan sumber daya lingkungan secara optimal melalui pembatasan sumber daya, mempertahankan proses ekologi, dan menjaga kelestarian serta keberadaan warisan alam dan keanekaragaman hayati pada destinasi wisata. Berkelanjutan secara ekonomi dilakukan dengan mengurangi tingkat kemiskinan, mendorong pertumbuhan ekonomi, dan penciptaan lapangan kerja. Sedangkan berkelanjutan secara sosial budaya dilakukan melalui menjaga keaslian sosial budaya masyarakat setempat dengan aturan dan ketentuan yang disepakati bersama, pelestarian nilai warisan budaya dan adat setempat, serta meningkatkan toleransi dan pemahaman antarbudaya.

Pulau-pulau kecil seperti telah diuraikan sebelumnya, memiliki keterbatasan sumber daya air dan lahan, sangat rentan terhadap pengaruh eksternal, sehingga dalam pengembangan pariwisata di pulau-pulau kecil perlu mempertimbangkan keberlanjutan ketiga aspek tersebut (sosial, ekonomi, dan ekologi) agar pariwisata yang dikembangkan dapat berkelanjutan.

\section{Teori Implementasi Kebijakan}

James Anderson mengemukakan bahwa: "Policy implementation is the application of 
the policy by the government's administrative machinery to the problem" (Tachjan, 2006: 24-25). Terjemahan bebasnya, implementasi kebijakan merupakan pelaksanaan kebijakan yang dilakukan oleh para pegawai pemerintahan untuk memecahkan masalah. Kebijakan tersebut perlu dituangkan dalam suatu peraturan perundang-undangan yang bersifat memaksa sehingga mempunyai kekuatan mengikat dan dipatuhi seluruh anggota masyarakat tanpa kecuali (Ramdani \& Ramdani, 2017). Oleh karena itu, tepat kiranya Kementerian Pariwisata mengeluarkan regulasi untuk mengembangkan pariwisata di pulau-pulau kecil agar berkelanjutan dalam bentuk Peraturan Menteri sebagai satu bentuk kebijakan.

Namun kebijakan yang disusun tidak akan berdampak jika tidak dilaksanakan. T.B. Smith menyatakan bahwa kebijakan harus diimplementasikan dan hasilnya sedapat mungkin sesuai dengan apa yang diharapkan oleh pembuat kebijakan (Nakamura \& Smallwood, 1980). Dalam implementasi kebijakan melibatkan sejumlah sumber, termasuk di dalamnya manusia, dana, dan kemampuan organisasional, baik dilakukan oleh pemerintah maupun swasta (Widodo, 2010).

Terkait hal tersebut, menurut Wahab, implementasi kebijakan dapat dilihat dari sudut pandang pembuat kebijakan, pejabat-pejabat pelaksana di lapangan, dan sasaran kebijakan (target group). Maksudnya, dari sudut pembuat kebijakan "sejauh mana kebijakan tersebut telah tercapai dan apa alasan yang menyebabkan keberhasilan atau kegagalan kebijakan tersebut". Dari sudut pejabat-pejabat pelaksana kebijakan dan instansi pelaksana di lapangan "apa tindakan pejabat dan instansi di lapangan untuk mencapai keberhasilan kebijakan". Sedangkan dari sudut pandang target group, "apakah implementasi kebijakan tersebut berdampak bagi kehidupan mereka, seperti dapat meningkatkan kesejahteraan mereka" (Wahab, 2008).

\section{Pariwisata di Karimunjawa}

Karimunjawa merupakan gugusan kepulauan berjumlah 27 pulau yang terletak di Laut Jawa, yang secara administrasi masuk dalam wilayah Kabupaten Jepara, Jawa Tengah. Luas Karimunjawa adalah 7.120 hektar atau $71,20 \mathrm{~km}^{2}$. Dari 27 pulau tersebut ada 5 pulau berpenghuni yaitu Pulau Karimunjawa (4.624 hektar atau 46,24 km²), Pulau Kemojan (1.626 hektar atau 16,26 km²), Pulau Nyamuk (139 hektar atau 1,39 $\mathrm{km}^{2}$ ), Pulau Parang (731 hektar atau 7,31 $\mathrm{km}^{2}$ ) (BPS Kabupaten Jepara, tt:4), dan Pulau Genting (BTNKJ, 2017). Pulau yang tidak berpenghuni meliputi Pulau Menjangan Besar (61 hektar), Menjangan Kecil (43,025), Cemara Besar, Cemara Kecil (1,5 hektar), Geleyang, Burung, Bengkoang (105 hektar), Kembar, Katang, Krakal Besar, Krakal Kecil, Sintok, Mrican, Tengah, Pinggir, Cilik, Gundul, Seruni, Tambangan, Cendekian, Kumbang, dan Mencawakan/ Menyawakan.² Belum semua pulau terdata luas wilayahnya. Jika melihat luas pulaunya, maka Karimunjawa termasuk dalam kategori pulau-pulau kecil.

Sebagian wilayah Karimunjawa merupakan kawasankonservasidalambentuk TamanNasional Karimunjawa (TNKJ). Dari 27 pulau yang ada 22 pulau masuk dalam kawasan TNKJ. Adapun luas TNKJ adalah 111.626 hektar (SK Menhut No. 78/Kpts-II/1999 tanggal 22 Februari 1999) yang terdiri dari daratan di Pulau Karimunjawa seluas 1.285,50 hektar dan di Pulau Kemojan seluas 222,20 hektar, serta perairan di sekitarnya seluas 110.117,30 hektar (Kep.Menhut No. 74/ Kpts-II/2001 tentang Penetapan Batas Sebagian Kawasan Taman Nasional Karimunjawa tanggal 14 Maret 2000). TNKJ dikelola oleh Balai Taman Nasional Karimunjawa (BTNK).

Pariwisata di Karimunjawa termasuk dalam Kawasan Strategis Pariwisata Nasional (KSPN), juga Kawasan Strategis Pariwisata Provinsi (KSPP) Jawa Tengah. Ada beberapa dokumen yang menjadi acuan pengembangan pariwisata di Karimunjawa yaitu dokumen Rencana Induk dan Rencana Detail KSPN Karimunjawa dan Sekitarnya, Rencana Induk Pengembangan Kepariwisataan Provinsi Jawa Tengah Tahun 2012 - 2027 (Peraturan Daerah Provinsi Jawa

\footnotetext{
Direktori Pulau-Pulau Kecil di Indonesia, http://www.ppkkp3k.kkp.go.id/direktori-pulau/index.php/public_c/pulau_ data diakses 4 April 2018.
} 
Tengah Nomor 10 Tahun 2012), dan Rencana Pengelolaan Jangka Panjang Taman Nasional Karimunjawa Tahun 2018 - 2027.

Pariwisata Karimunjawa dari sisi 4 komponen pariwisata adalah:

\section{Atraksi}

Atraksi wisata yang ditawarkan Karimunjawa adalah (Pemprov Jawa Tengah, 2016:2-5):

a. Wisata bahari. Aktivitas yang bisa dilakukan wisatawan antara lain snorkelling, diving, memancing, berenang, berjemur di pantai, bermain kano, mendayung, voli pantai, barbeque dipulau kecil, melihat sunrise atau sunset, bermain layang-layang. Lokasi snorkelling dan diving sebagian besar berada di dalam zona pemanfaatan wisata bahari TNKJ. Luas zona pemanfaatan wisata bahari adalah 2.733,735 hektar (sekitar 2,329\% dari luasan TNKJ) (BTNK, 2018:47). Adapun lokasi snorkelling berada di 27 titik, yaitu Batu Gundul, Kumbang, Krakal Besar, Krakal Kecil, Krang Kapal, Bengkoang, Menyawakan, Cemara Besar, Gosong Cemara Kecil, Cemara Kecil, Geleang, Nyamplungan, Menjangan Besar, Menjangan Kecil 1, Menjangan Kecil 2, Pantai Anora, Gosong Seloka, Sintok 1, Sintok 2, Tengah 1, Tengah 2, Kecil 1, Kecil 2, Kecil 3, Cendekian, Sambangan, dan Serun Gentingi. Sedangkan lokasi diving ada di 18 titik, yaitu di Kumbang, Katang, Utara Cemara Besar, Timur Laut Cemara Besar, Menyawakan, Cemara Kecil, Geleang, Cilik, Burung, Indonoor, Tanjung Gelam, Taka Menjangan Kecil, Menjangan Kecil (Kapal Genting), Menjangan Besar, Sintok, Tengah, dan Legon moto (Pemprov Jawa Tengah, 2016:2 - 4). Lokasi memancing berada di zona budidaya bahari TNKJ, yang luas kawasannya sekitar 1.370,729 hektar. Daerahnya adalah di perairan Pulau Karimunjawa, Pulau Kemujan, Pulau Menjangan Besar, Pulau Parang, Pulau Nyamuk, Pulau Karang Besi bagian utara (BTNK, 2018:47-48).

b. Wisata daratan. Aktivitas yang bisa dilakukan wisatawan antara lain trekking hutan mangrove, naik ke bukit melihat view laut ataupun sunrise dan sunset di Bukit Love dan Bukit Joko Tuo, bersepeda, tour motor trail, ziarah makam di makam Sunan Nyamplung. Trekking mangrove lokasinya berada di hutan mangrove sekitar perbatasan Pulau Karimunjawa dan Pulau Kemujan. Daerahnya masuk dalam kawasan TNKJ yaitu di zona pemanfaatan darat. Nama daerahnya adalah Terusan. Trekking mangrove ini diresmikan oleh Gubernur Jawa Tengah pada tahun 2012 dengan panjang trekking mencapai 1,37 km. Trekking mangrove dilengkapi dengan pusat informasi mangrove, sunset area, papan informasi, menara pandang dan shelters bagi para pengunjung. Aktivitas yang dapat dilakukan oleh pengunjung adalah menikmati keunikan pohon, mengamati satwa atau berinteraksi dengan para pemburu kerang di kawasan tersebut. Aktivitas tracking juga dapat dilakukan di hutan hujan tropis dataran rendah dengan pengawasan petugas (BTNK, 2018:24). Sedangkan makam Sunan Nyamplung, lokasinya berada di zona religi, budaya, dan sejarah dalam TNKJ. Luasnya sekitar 0,859 hektar dan berada di Pulau Karimunjawa (BTNK, 2018:48).

c. Wisata edukasi. Lokasinya ada di Fasilitas Penetasan Semi Alami Penyu. Di lokasi ini pengunjung dapat belajar tentang upaya konservasi penyu dan jika dimungkinkan dapat melakukan pelepasan tukik (BTNK, 2018:24).

d. Wisata budaya. Wisata budaya di Karimunjawa erat kaitannya dengan sejarah Karimunjawa yang dulunya merupakan tempat singgah beberapa etnis hingga akhirnya menetap dan hidup saling berdampingan dengan adat istiadat dan budaya masing-masing. Penduduk Karimunjawa terdiri dari berbagai etnis seperti Jawa, Madura, Bugis, Mandar, Bajau, Munak, dan Luwu. Masing-masing membawa adat istiadatnya dan menjadikan keragaman budaya ini satu daya tarik tersendiri di Karimunjawa. Beberapa keragaman budaya yang biasanya ditampilkan sebagai atraksi wisata adalah reog barongan, kuda lumping, rebana, pencak silat, perkawinan Suku Bugis, upacara peluncuran perahu (mappanok lopi), sedekah laut (lomban), upacara memindahkan rumah (mappalettek bola), upacara barikan. Di Karimunjawa juga terdapat makam Sunan Nyamplungan (yang dipercaya sebagai orang pertama yang mendiami Kecamatan Karimunjawa dan juga murid Sunan Kudus) dan Sumur Wali di Pulau Nyamuk. Sumur Wali merupakan sumur yang disucikan oleh masyarakat dengan kepercayaan airnya akan membawa keberuntungan bagi yang mengambilnya.

\section{Aksesibilitas}

Sebagai KSPN dan KSPP, Karimunjawa didukung oleh sarana prasarana transportasi baik darat, laut, maupun udara untuk memudahkan wisatawan mendatangi daerah tersebut. Transportasi laut dapat melalui Pelabuhan Kartini Jepara, Pelabuhan Tanjung Emas Semarang dan 
Tabel 4. Jadwal Pelayaran Menuju dari dan menuju Karimunjawa

\begin{tabular}{|c|c|c|c|c|c|c|c|}
\hline Kapal & Senin & Selasa & Rabu & Kamis & Jumat & Sabtu & Minggu \\
\hline $\begin{array}{l}\text { Kapal dari Pelabuhan Kartini Jepara menuju } \\
\text { Karimunjawa }\end{array}$ & & & & & & & \\
\hline KMP Siginjai & $\sqrt{ }$ & & $\sqrt{ }$ & & & $\sqrt{ }$ & \\
\hline KMC Express Bahari & $\sqrt{ }$ & $\sqrt{ }$ & & & $\sqrt{ }$ & & $\sqrt{ }$ \\
\hline $\begin{array}{l}\text { Kapal dari Karimunjawa menuju Pelabuhan } \\
\text { Kartini }\end{array}$ & & & & & & & \\
\hline KMP Siginjai & & $\sqrt{ }$ & & $\sqrt{ }$ & & & $\sqrt{ }$ \\
\hline KMC Express Bahari & $\sqrt{ }$ & & $\sqrt{ }$ & & & $\sqrt{ }$ & $\sqrt{ }$ \\
\hline $\begin{array}{l}\text { Kapal dari Pelabuhan Tanjung Emas Semarang } \\
\text { menuju Karimunjawa }\end{array}$ & & & & & & & \\
\hline KMC Kartini & & & & $\sqrt{ }$ & & & \\
\hline $\begin{array}{l}\text { Kapal dari Karimunjawa menuju Pelabuhan } \\
\text { Tanjung Emas }\end{array}$ & & & & & & & \\
\hline KMC Kartini & & & & & $\sqrt{ }$ & & \\
\hline
\end{tabular}

Sumber: Pemprov Jawa Tengah, 2016

Pelabuhan Kendal. Perjalanan menuju Pulau Karimunjawa dapat dilakukan menggunakan KMP Siginjai, KMC Express Bahari dari Jepara, dan KMC Kartini dengan jadwal pelayanan sebagai berikut:

Jadwal keberangkatan dengan menggunakan KMP Siginjai dari Pelabuhan Kartini Jepara jam 07.00 dengan waktu tempuh 4 jam. Sedangkan KMP Express Bahari berangkat jam 09.00 dengan waktu tempuh 2 jam. Untuk KMC Kartini waktu tempuh dari Semarang menuju Karimunjawa adalah 2,5 jam. Waktu tempuh dapat berubah jika gelombang tinggi dan peniadaan pelayaran dapat terjadi jika kondisi cuaca buruk, gelombang pasang, dan ombak tinggi.

Penyeberangan menuju Karimunjawa juga dapat dilakukan dengan menggunakan kapal nelayan, namun waktu tempuh lebih lama dan tarif sewa kapal tergantung kesepakatan dengan pemilik kapal. Sampai saat ini belum ada kapal yang melayani transportasi antar-pulau.

Transportasi udara menuju Karimunjawa saat ini baru dapat ditempuh dari Bandara Juanda Surabaya menuju Bandara Dewandharu di Pulau Kemojan, dengan kapasitas penumpang maksimal 10 penumpang. Jadwal penerbangan Surabaya Karimunjawa (PP) ada di hari Kamis dan Jum'at. Sementara untuk penerbangan dari Bandara Ahmad Yani menuju ke Bandara Dewandharu baru akan dijadwalkan di tahun 2019 dengan rencana jadwal pada hari Kamis dan Jumat (lihat Tabel 5).
Tabel 5. Jadwal Pelayaran Menuju dan dari Karimunjawa

\begin{tabular}{|c|c|c|c|c|}
\hline \multirow{3}{*}{ Bandara } & \multicolumn{4}{|c|}{ Jadwal Pesawat } \\
\hline & \multicolumn{2}{|c|}{ Keberangkatan } & \multicolumn{2}{|c|}{ Kedatangan } \\
\hline & Kamis & Jumat & Kamis & Jumat \\
\hline $\begin{array}{l}\text { Semarang - } \\
\text { Karimunjawa }\end{array}$ & 06.00 & 06.00 & 15.45 & 14.05 \\
\hline $\begin{array}{l}\text { Karimunjawa } \\
\text { - Semarang }\end{array}$ & 15.15 & 13.25 & 06.40 & 06.40 \\
\hline $\begin{array}{l}\text { Surabaya - } \\
\text { Karimunjawa }\end{array}$ & 12.35 & 11.00 & 08.15 & 08.15 \\
\hline $\begin{array}{l}\text { Karimunjawa } \\
\text { - Surabaya }\end{array}$ & 06.55 & 06.55 & 13.88 & 12.20 \\
\hline
\end{tabular}

Sumber: Pemprov Jawa Tengah, 2016

\section{Amenitas}

Karimunjawa juga didukung fasilitas informasi dan pelayanan pariwisata baik dari Dinas Pariwisata dan Kebudayaan Kabupaten Jepara, juga dari BTNK. Untuk melayani wisman terdapat fasilitas pelayanan keimigrasian di Jawa Tengah. Sedangkan fasilitas umum lainnya yang mendukung pariwisata di Karimunjawa antara lain (BPS Kabupaten Jepara, $t \mathrm{t}$ ):

a. Sarana peribadatan. Di Kecamatan Karimunjawa tercatat terdapat 14 buah masjid, 36 buah mushola, 2 buah Gereja pada tahun 2016.

b. Sarana kesehatan. Di Kecamatan Karimunjawa terdapat Puskesmas (yang dilengkapi dengan rawat inap), BKIA, bidan, paramedis, apotik dan juga tabib. Pada tahun 2016 ada 3 buah puskesmas, 1 buah BKIA, 7 orang bidang, 12 
orang paramedis, 1 buah apotik, dan 12 orang tabib di Kecamatan Karimunjawa.

c. Sarana perekonomian. Di Kecamatan Karimunjawa terdapat 1 pasar, 41 buah toko, 72 buah warung, 1 KUD dan 2 koperasi simpan pinjam.

d. Fasilitas perbankan yang melayani penukaran uang (money changer) dan fasilitas atm. Terdapat 1 bank umum dan 2 Bank Perkreditan Rakyat yang berada di Pulau Karimunjawa.

Adapun prasarana umum pendukung pariwisata di Karimunjawa meliputi (Pemerintah Provinsi Jawa Tengah, 2016: 8 - 9):

a. Jaringan kelistrikan. Sebagai wilayah kepulauan yang jauh dari Ibukota Jepara, Karimunjawa belum terlayani jaringan listrik PLN. Sumber energi listrik di Karimunjawa dipenuhi oleh Pembangkit Listrik Tenaga Diesel (PLTD) milik Pemerintah Daerah Kabupaten Jepara yang hanya menyala pada jam-jam tertentu. Saat ini ada sekitar 3.199 KK yang ada di Karimunjawa. PLTD baru melayani 2.681 pelanggan sehingga masih kurang $1.000 \mathrm{KK}$ lebih yang belum teraliri listrik.

b. Jaringan telekomunikasi yang tersedia adalah jaringan telekomunikasi nirkabel dari provider Telkomsel dan Indosat. Namun jaringan telekomunikasi tersebut baru tersedia di Pulau Karimunjawa.

c. Jaringan air bersih belum masuk ke wilayah Karimunjawa. Selama ini pemenuhan air bersih untuk hotel dan homestay diambil dari 1 buah tampungan air bersih yang bersumber dari sungai di atas bukit. Bahkan terkadang jika musim kemarau tiba, masyarakat terpaksa mengonsumsi air payau untuk kegiatan sehari-hari.

d. Jaringan drainase yang tersedia adalah drainase terbuka dan tertutup. Tetapi masih banyak jaringan jalan di Kecamatan Karimunjawa yang tidak dilengkapi dengan saluran drainase sehingga menyebabkan genangan air dan kerusakan jalan. Jaringan drainase yang ada pun seringkali tidak berfungsi karena tersumbat oleh tumpukan sampah.

e. Sarana pengelolaan sampah. Di Karimunjawa belum terdapat tempat pengolahan sampah akhir, dan sampah plastik menjadi permasalahan di Karimunjawa seiring dengan pesatnya perkembangan pariwisata di Karimunjawa.

Di Karimunjawa banyak tersedia penginapan, baik dalam bentuk hotel (ada 11 hotel di Pulau Karimunjawa dan 4 hotel di Pulau
Kemojan) ataupun dalam bentuk hosmen/motel/ losmen/wisma/homestay (ada 73 buah di Pulau Karimunjawa, 4 buah di Pulau Kemojan, dan 1 buah di Pulau Parang). Selain itu juga tersedia toko, kios, warung, rumah makan dan warung makan di empat pulau yang berpenghuni, yaitu di Pulau Karimunjawa, Pulau Kemojan, Pulau Parang, dan Pulau Nyamuk (Tabel 6) (BPS Kabupaten Jepara, $t \mathrm{t}$ ).

Tabel 6. Toko, Kios, Warung, Rumah Makan dan Warung Makan di Kecamatan Karimunjawa Tahun 2016

\begin{tabular}{lcccc}
\hline \multicolumn{1}{c}{ Desa } & $\begin{array}{c}\text { Toko/ } \\
\text { kios }\end{array}$ & warung & $\begin{array}{c}\text { Restoran/ } \\
\text { warung } \\
\text { makan }\end{array}$ & $\begin{array}{c}\text { Warung } \\
\text { makan }\end{array}$ \\
\hline Karimunjawa & 28 & 35 & 6 & 15 \\
Kemojan & 8 & 21 & - & 6 \\
Parang & 3 & 10 & - & 3 \\
Nyamuk & 2 & 6 & - & 2 \\
Jumlah & 41 & 72 & 6 & 26 \\
\hline
\end{tabular}

Sumber: BPS Kabupaten Jepara (tt)

\section{Ancillary Services}

Untuk menunjang pengembangan pariwisata diperlukan organisasi-organisasi kepariwisataan yang dibutuhkan untuk pelayanan wisatawan. Di Karimunjawa baru ada beberapa organisasi kepariwisataan seperti:

a. Himpunan Pemandu Indonesia (HPI), merupakan organisasi yang mewadahi pemandu wisata di Karimunjawa.

b. Trans Karimunjawa, merupakan organisasi yang mewadahi para penyedia penyewaan mobil di Karimunjawa.

c. Forum Tour Guide, merupakan organisasi yang mewadahi tour guide di Karimunjawa.

d. Paguyuban Pengelola Homestay, merupakan organisasi yang mewadahi pengelola homestay di Karimunjawa.

\section{Implementasi Kebijakan dari Sudut Pandang Pembuat Kebijakan}

Arah pembangunan pariwisata nasional adalah pengembangan kepariwisataan dengan memanfaatkan keragaman pesona keindahan alam dan potensi nasional sebagai wilayah wisata bahari terluas di dunia secara arif dan berkelanjutan, serta mendorong kegiatan ekonomi yang terkait pengembangan budaya bangsa (RPJPN 2005-2025). Terkait pariwisata di pulau- 
pulau kecil, arah pembangunan ini kemudian diterjemahkan oleh beberapa kementerian terkait dengan mengeluarkan kebijakan sesuai dengan kewenangannya.

Kementerian Pariwisata mengeluarkan kebijakan kepariwisataan melalui UU No. 10 Tahun 2009 tentang Kepariwisataan. Dalam UU tersebut tujuan kepariwisataan adalah untuk meningkatkan pertumbuhan ekonomi; meningkatkan kesejahteraan rakyat; menghapus kemiskinan; mengatasi pengangguran; melestarikan alam, lingkungan, dan sumber daya; memajukan kebudayaan; mengangkat citra bangsa; memupuk rasa cinta tanah air; memperkukuh jati diri dan kesatuan bangsa; dan mempererat persahabatan antarbangsa. Prinsip dalam penyelenggaraan kepariwisataan antara lain memberi manfaat untuk kesejahteraan rakyat, keadilan, kesetaraan, dan proporsionalitas; memelihara kelestarian alam dan lingkungan hidup; memberdayakan masyarakat setempat; dan menjamin keterpaduan antarsektor, antardaerah, antara pusat dan daerah yang merupakan satu kesatuan sistemik dalam kerangka otonomi daerah serta keterpaduan antarpemangku kepentingan.

Terkait wilayah pulau-pulau kecil, Kementerian Pariwisata mengeluarkan kebijakan pengembangan wisata bahari (marine tourism). Wisata bahari meliputi wisata pantai (coastal zone), wisata bentang laut (sea zone), dan wisata bawah laut (underwater zone). Target wisata bahari tahun 2019 adalah:

a. jumlah wisman 4 juta orang;

b. devisa 4 miliar US\$;

c. 19 KSPN bahari untuk pengembangan wisata pantai;

d. 6000 kapal yacht dan 1000 kunjungan cruise untuk pengembangan wisata bentang laut;

e. 45 destinasi selam untuk pengembangan wisata bawah laut.

Untuk menindaklanjuti UU No. 10 Tahun 2009, maka Kementerian Pariwisata mengeluarkan PP No. 50 Tahun 2011 tentang Rencana Induk Pembangunan Kepariwisataan Nasional (Ripparnas) Tahun 2010 - 2025. Dalam Ripparnas tersebut dinyatakan bahwa Karimunjawa dan sekitarnya merupakan kawasan Strategis Pariwisata Nasional (KSPN) dan dalam pengembangannya perlu disusun rencana induk dan rencana detail.

Agar pengembangan pariwisata di pulaupulau kecil berkelanjutan, Kementerian Pariwisata sebelumnya sudah membuat pedoman melalui Peraturan Menteri Kebudayaan dan Pariwisata (Permenbudpar) Nomor: KM.67/ UM.001/MKP/2004 tentang Pedoman Umum Pengembangan Pariwisata di Pulau-Pulau Kecil. Menurut peraturan tersebut, pengembangan pariwisata di pulau-pulau kecil harus berpegang pada 5 prinsip, yaitu:

a. Prinsip keseimbangan, bahwa pengelolaan pariwisata di pulau-pulau kecil didasarkan pada komitmen pola keseimbangan antara pembangunan ekonomi, sosial budaya, dan konservasi;

b. Prinsip partisipasi masyarakat, bahwa pengembangan pariwisata di pulau-pulau kecil melibatkan masyarakat dalam pengelolaan usaha pariwisata;

c. Prinsip konservasi, bahwa pengembangan pariwisata di pulau-pulau kecil memiliki kepedulian, tanggung jawab dan komitmen terhadap pelestarian lingkungan (alam dan budaya). Pengembangan harus diselenggarakan secara bertanggung jawab dan mengikuti kaidahkaidah ekologi serta peka dan menghormati nilai-nilai sosial budaya dan tradisi keagamaan masyarakat setempat;

d. Prinsip keterpaduan, bahwa pengelolaan pariwisatadipulau-pulaukecil harus direncanakan secara terpadu dengan memperhatikan ekosistem pulau dan disinergikan dengan pembangunan berbagai sektor;

e. Prinsip penegakan hukum, bahwa pengelolaan pariwisata di pulau-pulau kecil harus dikembangkan sesuai dengan aturan hukum yang ada.

Dalam pengembangan pariwisata di pulaupulau kecil tersebut diarahkan agar ada:

a. Penataan ruang yang jelas, yang dalam penyusunannya harus melalui proses konsultatif dengan para pihak, merupakan hasil kolaborasi masukan para pihak dengan perencana kawasan, dan memperhatikan aspek lingkungan (termasuk konservasi sumber daya alam dan sensitivitas ekosistem) serta aspek sosial, budaya, dan ekonomi masyarakat. Dalam hal ini, penyusunan dan penetapan zonasi diperlukan. Umumnya jenis zonasi yang digunakan dalam pengembangan 
pariwisata adalah zona intensif ${ }^{3}$, zona ekstensif $^{4}$, dan zona perlindungan ${ }^{5}$.

b. Pendekatan daya dukung (carrying capacity). Daya dukung diartikan sebagai kondisi maksimum suatu ekosistem untuk menampung komponen biotik (makhluk hidup) yang terkandung di dalamnya dengan juga memperhitungkan faktor lingkungan dan faktor lainnya yang berperan di alam. Secara umum ragam daya dukung wisata di pulau-pulau kecil meliputi: (1) daya dukung ekologis (merupakan tingkat maksimal penggunaan suatu pulau); (2) daya dukung fisik (merupakan jumlah maksimum penggunaan atau kegiatan yang dapat diakomodir tanpa menyebabkan kerusakan atau penurunan kualitas); dan (3) daya dukung sosial (merupakan batas tingkat maksimum dalam jumlah dan tingkat penggunaan yang akan menimbulkan penurunan dalam tingkat kualitas pengalaman atau kepuasan pengunjung di pulau-pulau kecil).

c. Pengembangan sarana dan prasarana dalam rangka pengembangan pariwisata dilakukan dengan tetap menjaga aspek keberlanjutan, sehingga dalam pengembangan sarana dan prasarana pariwisata dilakukan melalui studi AMDAL/UKL-UPL.

d. Pengembangan pariwisata direncanakan dan dikembangkan secara ramah lingkungan dengan tidak menghabiskan atau merusak sumber daya alam dan sosial, namun dipertahankan untuk pemanfaatan yang berkelanjutan.

Ketika wilayah pesisir dan pulau-pulau kecil akan dikembangkan, termasuk untuk kegiatan pariwisata, pengembangannya juga harus memperhatikan aturan dari Kementerian Kelautan dan Perikanan yaitu UU No. 27 Tahun 2007 tentang Pengelolaan Wilayah Pesisir dan Pulau-

Zona intensif adalah suatu kawasan yang dirancang untuk dapat menerima kunjungan dan tingkat kegiatan yang tinggi dengan memberikan ruang yang luas untuk kegiatan dan kenyamanan pengunjung. Dalam zona ini dapat dikembangkan sarana dan prasarana fisik untuk pelayanan pariwisata yang umumnya tidak melebihi $60 \%$ luas kawasan zonasi intensif dan memperhatikan daya dukung lingkungan.

Zona ekstensif adalah suatu kawasan yang dirancang untuk menerima kunjungan dan tingkat kegiatan terbatas, untuk menjaga kualitas karakter sumber daya alam. Dalam zona ini kegiatan pengunjung harus dapat dikontrol dan pembangunan sarana dan prasarana terbatas hanya untuk pengunjung kegiatan, seperti jalan setapak, tempat istirahat, menara pandang, papan penunjuk dan informasi.

5 Zona perlindungan adalah suatu kawasan yang dirancang untuk tidak menerima kunjungan dan kegiatan pariwisata. Kawasan ini biasanya merupakan kawasan yang menjadi sumber air bagi kawasan seluruh pulau atau memiliki kerentanan keanekaragaman yang sangat tinggi.
Pulau Kecil (yang telah diperbaharui dengan UU No. 1 Tahun 2014). Dalam UU tersebut dinyatakan bahwa pengelolaan pesisir dan pulau-pulau kecil harus didasarkan perencanaan (rencana strategis, rencana zonasi, rencana aksi). Terkait pulau-pulau kecil, Kementerian Kelautan dan Perikanan mengeluarkan Permen KP. No. 34/Permen-KP/2014 tentang Perencanaan Pengelolaan Wilayah Pesisir dan Pulau-Pulau Kecil. Peraturan ini dikeluarkan agar terwujud perencanaan pengelolaan wilayah pesisir dan pulau-pulau kecil secara terpadu pada tingkat pemerintah daerah provinsi dan/atau pemerintah daerah kabupaten/kota. Prinsip perencanaannya adalah: (1) merupakan satu kesatuan yang tidak terpisahkan dan/atau komplemen dari sistem perencanaan pembangunan daerah; (2) mengintegrasikan kegiatan antara pemerintah dengan pemerintah daerah, antarsektor, antara pemerintahan, dunia usaha dan masyarakat, antara ekosistem darat dan ekosistem laut, dan antara ilmu pengetahuan dan prinsip-prinsip manajemen; (3) dilakukan sesuai dengan kondisi biogeofisik dan potensi yang dimiliki masingmasing daerah, serta dinamika perkembangan sosial budaya daerah dan nasional; dan (4) melibatkan peran serta masyarakat setempat dan pemangku kepentingan lainnya.

Mengingat destinasi di Karimunjawa juga merupakan kawasan konservasi dalam bentuk Taman Nasional, maka dalam pengelolaannya juga mengacu pada kebijakan Kementerian Lingkungan Hidup dan Kehutanan tentang pengelolaan kawasan konservasi. Adapun kebijakan Kementerian Lingkungan Hidup dan Kehutanan tersebut didasarkan pada UU No. 5 Tahun 1990 tentang Konservasi Sumber Daya Alam Hayati dan Ekosistemnya dan peraturan pelaksananya (PP No. 28 Tahun 2011 tentang Pengelolaan Kawasan Suaka Alam dan Kawasan Pelestarian Alam). Mengacu pada aturan tersebut, maka kawasan Karimunjawa yang masuk dalam Taman Nasional Karimunjawa, pengelolaannya dilakukan secara zonasi. Di mana dalam pengelolaan Taman Nasional Karimunjawa tersebut ada tiga kegiatan utama yang harus dilakukan yaitu perlindungan sistem penyangga kehidupan, pengawetan keanekaragaman jenis 
tumbuhan dan satwa beserta ekosistemnya, dan pemanfaatan secara lestari sumber daya alam hayati dan ekosistemnya. Untuk pengembangan pariwisata dapat dilakukan di zona pemanfaatan.

Mengingat pengembangan pariwisata itu melibatkan banyak kementerian/lembaga, maka Pemerintah mengeluarkan Peraturan Presiden Nomor 64 Tahun 2014 tentang Koordinasi Strategis Lintas Sektor Penyelenggaraan Kepariwisataan. Ada 14 kementerian/ lembaga yang dikoordinasikan dalam Perpres tersebut. Terkait pariwisata yang dikembangkan di kawasan konservasi juga telah ada nota kesepahaman antara Kementerian Pariwisata dengan Kementerian Lingkungan Hidup dan Kehutanan (Nota Kesepahaman Antara Kementerian Pariwisata dengan Kementerian Lingkungan Hidup dan Kehutanan tentang Percepatan Pengembangan Pariwisata di Kawasan Hutan Nomor: NK.6/ KS.001/MP/2015 dan Nomor: NK.10/MenLHKKSDAE/2015).

Nota kesepahaman tersebut mengatur tentang peningkatan kualitas pengelolaan pariwisata di kawasan hutan, peningkatan kualitas pengembangan pariwisata di kawasan hutan, dan peningkatan pemasaran pariwisata di kawasan hutan. Masing-masing pihak (Kementerian Pariwisata dan Kementerian Lingkungan Hidup dan Kehutanan) mempunyai tugas dan kewajiban dalam mengembangkan pariwisata di kawasan konservasi sesuai kewenangannya. Namun Taman Nasional Karimunjawa tidak masuk dalam daftar pengelolaan yang dilakukan secara bersama.

\section{Implementasi Kebijakan dari Sudut Pandang Pelaksana Kebijakan}

Pelaksanaan kebijakan pengembangan pariwisata di Karimunjawa mengacu pada kebijakan-kebijakan di atas (kebijakan dari Kementerian Pariwisata, Kementerian Kelautan dan Perikanan, dan Kementerian Lingkungan Hidupdan Kehutanan). Adabeberapastakeholders yang terlibat dalam pelaksanaan kebijakan pengembangan pariwisata Karimunjawa, yaitu:

a. Dinas Pemuda, Olah Raga, dan Pariwisata (Disporapar) Provinsi Jawa Tengah

b. Dinas Kelautan dan Perikanan (DKP) Provinsi
Jawa Tengah

c. Dinas Pariwisata dan Kebudayaan (Disparbud) Kabupaten Jepara.

d. Balai Taman Nasional Karimunjawa (BTNK) yang merupakan UPT Kementerian Lingkungan Hidup dan Kehutanan.

Ripparnas 2010 - 2025 ditindaklanjuti oleh Pemerintah Daerah Provinsi Jawa Tengah dengan menyusun Rencana Induk Pembangunan Kepariwisataan Provinsi Jawa Tengah Tahun 2012 - 2027 dalam bentuk Peraturan Daerah Provinsi Jawa Tengah No. 10 Tahun 2012. Rencana induk tersebut ditindaklanjuti dengan Peraturan Gubernur Jawa Tengah No. 6 Tahun 2015 tentang Petunjuk Pelaksanaan Perda Provinsi Jawa Tengah No. 10 Tahun 2012. Pergub ini menjadi acuan dalam penyusunan Rencana Detail KSPP Karimunjawa oleh pemerintah daerah dan para pemangku kepentingan.

Disporapar Jateng tahun 2017 sudah menyusun masterplan Karimunjawa. Dalam masterplan tersebut Kepulauan Karimunjawa (27 pulau kecil dengan 22 pulau berada dalam kawasan Taman Nasional Karimunjawa) akan dikembangkan menjadi destinasi wisata ke peminatan khusus (snorkelling, diving, berjemur di pantai). Harapannya tidak terjadi mass tourism di kawasan pariwisata Karimunjawa karena wilayahnya merupakan kawasan konservasi. Selain itu agar pariwisata di Karimunjawa dapat berkelanjutan. Selain menyusun Rippda dan masterplan, Disporapar Jateng juga melakukan pembinaan terhadap SDM pariwisata di Karimunjawa, yaitu dengan membantu para pramuwisata (tour guide) tersertifikasi. Sertifikasi dilakukan oleh BSNP (Badan Standarisasi Nasional Pariwisata). Dari 180 an tour guide 80 di antaranya telah tersertifikasi (Disporapar, wawancara, 7 Mei 2018).

Disparbud Kabupaten Jepara dalam pengembangan pariwisata Karimunjawa melakukan promosi dan pembinaan terhadap masyarakat di Karimunjawa. Pembinaan dilakukan terhadap pokdarwis (kelompok sadar wisata), pelaku wisata (pengelola homestay, pembuat souvenir, penyewaan perahu wisata dan alat-alat snorkelling dan diving, warung-warung 
makan). Dalam rangka meningkatkan kapasitas sumber daya manusia Karimunjawa, Disparbud Kabupaten Jateng melakukan pelatihan bahasa inggris, guide, dan pengelolaan homestay (Dinas Pariwisata dan Kebudayaan Kabupaten Jepara, wawancara, 9 Mei 2018). Sedangkan DKP Provinsi Jawa Tengah terkait pulau-pulau di Karimunjawa saat ini sedang menyusun Rencana Zonasi seperti yang diamanatkan UU No. 27 tahun 2007 (Dinas Kelautan dan Perikanan Provinsi Jawa Tengah, wawancara, 8 Mei 2018).

Sementara itu, Balai Taman Nasional Karimunjawa selaku pihak yang kawasannya dimanfaatkan untuk pariwisata telah menyusun zonasi yang telah ditetapkan dengan Keputusan Dirjen PHKA No. SK 28/IV/Set/2012. Pembagian zona di Taman Nasional Karimunjawa adalah zona inti, zona rimba, zona perlindungan bahari, zona pemanfaatan darat, zona pemanfaatan wisata bahari, zona budidaya bahari, zona religi, budaya, dan sejarah, zona rehabilitasi, dan zona tradisional perikanan (Balai Taman Nasional Karimunjawa, wawancara, 8 Mei 2018). Namun kepatuhan masyarakat lokal terhadap zonasi belum sesuai harapan, misalnya kepatuhan terhadap zona inti dan perlindungan pada tahun 2015 adalah 78,56\% (Yuliana et al., 2016), menurun dibandingkan dengan tingkat kepatuhan tahun 2009-2010 yaitu 84,87\% (BTNKJ, 2013). Penurunan terjadi karena masih rendahnya kesadaran masyarakat akan konservasi sumber daya pesisir dan laut, pengawasan yang belum optimal dari BTNKJ dan masyarakat, serta tanda batas zona yang tidak jelas (Yuliana et al., 2016). Untuk itu BTNK melakukan beberapa hal: (1) sosialisasi dan penyuluhan kepada masyarakat lokal tentang zonasi dan peruntukannya; (2) melibatkan masyarakat dalam melakukan upayaupaya konservasi seperti membersihkan sampah plastik di wilayah perairan Karimunjawa; (3) melakukan operasi terhadap pelanggaran di kawasan TNKJ (Seksi Pengembangan Taman Nasional Wilayah II Karimunjawa, wawancara, 12 Mei 2018) .

Meskipun dalam masterplan pengembangan pariwisata di Karimunjawa diarahkan untuk pengembangan pariwisata peminatan khusus agar tidak terjadi mass tourism (Disporapar Provinsi Jawa Tengah, wawancara, 8 Mei 2018), namun laju kunjungan wisatawan ke Karimunjawa dari waktu ke waktu terus mengalami peningkatan, terutama disaat weekend dan peak season. Pada tahun 2013 jumlah kunjungan wisatawan mancanegara ke Karimunjawa sebanyak 14.417 orang, meningkat tajam di tahun 2016 menjadi 21.288 orang. ${ }^{6}$ Kondisi ini cukup mengkhawatirkan bagi kondisi lingkungan di Karimunjawa. Ironisnya, Disporapar Provinsi Jawa Tengah pada Festival Karimunjawa tanggal 25 - 30 September 2018 menargetkan sebanyak 15.000 wisatawan dengan 30\% (5.000 orang) di antaranya wisatawan mancanegara diharapkan mengunjungi Karimunjawa. ${ }^{7}$ Pemerintah Daerah Provinsi Jawa Tengah tidak konsisten dengan rencana mereka dalam pengembangan pariwisata Karimunjawa, yang diarahkan pada pariwisata peminatan khusus yang tidak mass tourism.

Mass tourism tidak sesuai untuk destinasi pariwisata dengan keindahan alam sebagai daya tarik wisatanya. Apalagi untuk destinasi pariwisata yang merupakan pulau-pulau kecil yang memiliki keterbatasan (sumber daya air tawar terbatas dan rentan terhadap pengaruh eksternal termasuk karena kegiatan manusia). Mass tourism membutuhkan ketersediaan lahan yang luas untuk akomodasi dan sumber air bersih untuk memenuhi kebutuhan wisatawan. Pulau kecil seperti Karimunjawa tidak mampu untuk memenuhi berbagai hal tersebut. Perlu ada kajian tentang daya dukung (lingkungan, fisik, sosial) untuk mengetahui berapa wisatawan yang dimungkinkan untuk di tampung di Karimunjawa, baik di wilayah daratnya, di spot-spot snorkelling ataupun diving. Sistem penetapan target jumlah pengunjung menjadi kurang tepat diterapkan untuk wisata alam. Tetapi lama kunjungan dimungkinkan untuk ditingkatkan dengan menambah atraksi-atraksi lainnya dalam satu

Pesona Karimunjawa Dongkrak Kunjungan Turis Asing ke Jepara, 26 April 2017, http://jateng.metrotvnews. com/bisnis/ob3Box5N-pesona-karimunjawa-dongkrakkunjungan-turis-asing-ke-jepara, diakses 7 September 2018. Hingga Agustus, 660.000 Wisatawan Mancanegera Kunjungi Jawa Tengah. Kompas.com, 26 September 2018, https://ravel. kompas.com/read/2018/09/26/111200027/ hingga-agustus-660.000-wisatawan-mancanegarakunjungi-jawa-tengah diakses 5 November 2018. 
kawasan destinasi wisata.

Permasalahan yang muncul seiring dengan berkembangnya pariwisata di Karimunjawa saat ini adalah sampah, baik darat ataupun di perairan. Permasalahan sampah tidak dapat diatasi oleh pelaksana kebijakan, dalam hal ini Balai Taman Nasional Karimunjawa karena pengelolaan sampah tidak termasuk dalam kewenangannya (Seksi Pengembangan Taman Nasional Wilayah II Karimunjawa, wawancara, 12 Mei 2018). Hal itu memperlihatkan bahwa pengembangan pariwisata harus melibatkan berbagai sektor dengan berbagai stakeholders. Karena dalam pengembangan pariwisata ada 4 hal yang harus dipenuhi yaitu atraksi (daya tarik yang ditawarkan oleh suatu kawasan), aksesibilitas (akses transportasi yang tersedia menuju dan di dalam kawasan), amenitas (akomodasi dan fasilitas yang tersedia di kawasan), dan ancillary services (organisasi kepariwisataan yang dibutuhkan untuk pelayanan wisatawan). Ketika suatu kawasan ditetapkan menjadi destinasi tujuan wisata maka perlu ada lahan atau ruang untuk membangun akomodasi seperti penginapan, restoran, fasilitas kesehatan, fasilitas pengelolaan sampah dan limbah, ketersediaan air bersih, ketersediaan listrik, jaringan komunikasi; lahan atau ruang untuk membangun jalan, bandara, pelabuhan, dan lain sebagainya untuk memenuhi sarana aksesibilitas. Penyediaan berbagai fasilitas tersebut perlu melibatkan berbagai stakeholders, seperti penyediaan layanan kesehatan dengan melibatkan puskesmas atau rumah sakit, penyediaan air bersih dengan melibatkan PDAM setempat, penyediaan listrik dengan melibatkan PLN, penyediaan pengelolaan limbah dan sampah dengan melibatkan Dinas Lingkungan Hidup dan Dinas Kebersihan, penyediaan sarana transportasi dengan melibatkan Dinas Perhubungan, penyediaan jalan dan infrastruktur lainnya dengan melibatkan Dinas Pekerjaan Umum, dan lain sebagainya. Dengan pelibatan berbagai stakeholders yang lebih luas maka pengembangan pariwisata dapat berkelanjutan.

Untuk itu perlu ada perencanaan yang terintegrasi yang melibatkan berbagai sektor dan berbagai stakeholders, di mana rencana tersebut di dalamnya mengatur tentang:

a. penataan ruang yang disesuaikan dengan RTRWnya, dan dalam penyusunannya melibatkan berbagai pihak yang terkait;

b. perhitungan daya dukungnya (carrying capacity) yang meliputi daya dukung ekologis, daya dukung fisik, dan daya dukung sosial;

c. studi AMDAL atau UKL/UPL nya;

d. perhitungan pemanfaatan sumber daya alam secara ramah lingkungan, dan

e. hal yang harus dilakukan setiap stakeholders yang terlibat dalam pengembangan pariwisata.

Perencanaan terintegrasi ini diharapkan nantinya dapat mewujudkan lima prinsip yang ditetapkan oleh Kementerian Pariwisata dalam pengembangan wisata di pulau-pulau kecil sebagaimana diatur dalam Permenbudpar No. KM.67/UM.001/MKP/2004 tentang Pedoman Umum Pengembangan Pariwisata di PulauPulau Kecil, yaitu prinsip keseimbangan, prinsip partisipasi masyarakat, prinsip konservasi, prinsip keterpaduan, dan prinsip penegakkan hukum.

Hingga saat penelitian dilakukan, BTNK selaku pengelola TNKJ dan Pemerintah Daerah Provinsi Jawa Tengah yang juga terlibat dalam pengembangan pariwisata Karimunjawa, belum melakukan perhitungan daya dukung pariwisata di Karimunjawa. Meskipun hasil penelitian Limbong dan Soetomo (2014) menunjukkan telah terjadi kerusakan ekologis di kawasan TNKJ, seperti semakin luasnya kawasan terumbu karang yang rusak dan berkurangnya ketersediaan air bersih di kepulauan Karimunjawa.

\section{Implementasi Kebijakan dari Sudut Pandang Target Group}

Dari sudut pandang masyarakat Karimunjawa sebagai target group pengembangan pariwisata Karimunjawa, pariwisata telah berdampak terhadap kondisi sosial, ekonomi, dan lingkungan di Karimunjawa. Dampak ekonomi yang dirasakan masyarakat adalah:

- Bertambahnya lapangan kerja. Masyarakat yang sebagian besar tadinya merupakan nelayan, saat ini banyak yang kemudian mempunyai pekerjaan lain seperti menjadi Tour Guide, Tour Leader, jasa penyewaan kapal dan alat snorkelling/diving, jasa 
homestay, jasa penyewaan kendaraan, membuka warung jajanan, toko souvenir (pelaku wisata Karimunjawa, wawancara, 1 Mei 2018). Namun bertambahnya lapangan kerja ini tidak diimbangi dengan pengembangan kapasitas SDM masyarakat oleh pemerintah daerah. Pelatihan dan pembinaan yang dilakukan oleh Dinas Pariwisata Kabupaten Jepara terkesan hanya formalitas menurut pandangan masyarakat. Seperti pelatihan bahasa Inggris yang hanya dilakukan dalam 2 hari. Namun sertifikasi Tour Guide yang diselenggarakan Dinas Pariwisata Provinsi Jawa Tengah cukup membantu para tour guide Karimunjawa untuk mendapatkan sertifikasi BSNP (Badan Sertifikasi Nasional Pariwisata).

- Pekerjaan baru menambah pendapatan dan meningkatkan kesejahteraan mereka. Seperti pendapatan dari tour guide untuk kegiatan snorkelling minimal Rp.150.000 per hari, sedang dari ke diving minimal Rp.250.000 per hari; pendapatan dari homestay dengan harga per kamar dari Rp.150.000 s.d Rp.600.000 per hari, pendapatan dari penyewaan kapal mulai dari Rp.700.000 per kapal atau Rp.250.000 per orang mengikuti open trip, pendapatan dari penyewaan motor Rp. 75.000 per hari, penyewaan mobil mulai dari Rp.450.000 per hari, penyewaan alat snorkelling Rp.60.000 per orang. Pendapatan dari warung jajanan (seperti yang di Ujung Gelam) sekitar Rp.2.000.000 per bulan. Namun ketika gelombang tinggi pendapatan hanya Rp.500.000 s.d Rp.750.000 per bulan. Pendapatan dari toko souvenir mulai dari Rp.1.000.000 s.d. Rp.5.000.000 per bulan, tergantung kondisi banyak tidaknya kapal datang (pelaku wisata Karimunjawa, wawancara, 11-12 Mei 2018).

- Pariwisata Karimunjawa juga menarik masyarakat luar membuka usaha di Karimunjawa. Muncul kafe, restoran, hotel, yang izin usahanya dikeluarkan oleh Pemerintah Daerah Kabupaten Jepara. Saat ini ada 10 hotel, 2 restoran, 101 homestay (Dinas Pariwisata dan Kebudayaan Kabupaten Jepara, wawancara, 9 Mei 2018).

Sedangkan dampak sosial yang dirasakan masyarakat dari pariwisata antara lain mulai luntur rasa kepedulian antar anggota masyarakat, budaya wisatawan asing sudah memengaruhi pola pergaulan dan cara berpakaian anak-anak muda, muncul kegiatan party di kafe-kafe hotel yang berpengaruh terhadap pola pergaulan anak-anak muda, minuman beralkohol mudah didapatkan (masyarakat Karimunjawa, wawancara, 12 Mei 2018). Untuk mengurangi dampak sosial, masyarakat membuat aturan tidak tertulis dengan menghimbau kepada para wisatawan asing untuk berpakaian sopan ketika di tempat umum.

Adapun dampak lingkungan yang dirasakan oleh masyarakat dengan adanya pariwisata adalah:

- Sampah yang belum terkelola dengan baik, baik sampah di darat ataupun di perairan, terutama sampah plastik. Kondisi saat ini hanya tersedia 3 TPS yang belum menerapkan 3R. Pemerintah Daerah Kabupaten Jepara merencanakan akan membangun TPA di pulau Karimunjawa, dibantu pemerintah pusat (KemenPUPR).

- Ketersediaan air bersih terancam karena terjadinya alih fungsi daerah resapan di kawasan perbukitan untuk hotel, homestay, dan sejumlah infrastruktur (bandar udara, sekolah, kantor pemerintahan) dalam 2 tahun terakhir. Saat ini pasokan air bersih masyarakat Karimunjawa hanya berasal dari sumber air dari kawasan perbukitan. Kesulitan air bersih sering dirasakan masyarakat pada bulan Juni - September.

- Kerusakan terumbu karang. Penelitian Biondi dkk. (2014) memperlihatkan persentase tutupan terumbu karang hidup pada lokasi wisata snorkelling di TNKJ sebesar 33\% $52,5 \%$ masuk dalam kategori buruk-baik. Persentase tutupan terendah ada di perairan Pulau Menjangan Kecil (33\%) dan terbaik ada di perairan Pulau Sinto (52,5\%).

Berbagai permasalahan lingkungan tersebut sudah diupayakan untuk diatasi. Seperti untuk masalah sampah, BTNK bekerja sama dengan masyarakat melakukan bersih pantai dan bersih perairan sebulan sekali. Untuk masalah air bersih, di tahun 2018 ini direncanakan PDAM Kabupaten 
Jepara akan turun mengelola sumber daya air di Karimunjawa untuk memenuhi kebutuhan air bersih masyarakat. Ada 2 opsi yang akan dilakukan oleh PDAM untuk mengatasinya yaitu dengan membuat embung atau membendung teluk. Sedangkan untuk mengurangi kerusakan terumbu karang akibat aktivitas snorkelling, masyarakat bersepakat untuk menutup sementara daerah Maer yaitu perairan sekitar Pulau Menjangan Kecil (1 jam perjalanan dengan kapal kayu) selama 3 tahun agar kawasan tersebut dapat pulih kembali. Selain tour guide menghimbau kepada para wisatawan untuk tidak memegang biota laut dan menginjak karang selama aktivitas snorkelling dilakukan.

\section{Penutup \\ Simpulan}

Pengembangangan

pariwisata

di

Karimunjawa didasarkan pada arah pembangunan kepariwisataan sebagaimana yang tertuang dalam RPJPN 2005-2025 bahwa pengembangan kepariwisataan dilakukan dengan memanfaatkan keragaman pesona keindahan alam dan potensi nasional sebagai wilayah wisata bahari terluas di dunia secara arif dan berkelanjutan, serta mendorong kegiatan ekonomi yang terkait pengembangan budaya bangsa. Arah pembangunan tersebut kemudian diterjemahkan oleh Kementerian Pariwisata, Kementerian Kelautan dan Perikanan, dan Kementerian Lingkungan Hidup dan Kehutanan dalam bentuk peraturan di sektor masing-masing. Kebijakan sektor tersebut dilaksanakan oleh Dinas Pemuda, Olahraga, dan Pariwisata (Disporapar) Provinsi Jawa Tengah, Dinas Kelautan dan Perikanan (DKP) Provinsi Jawa Tengah, Dinas Pariwisata dan Kebudayaan (Disparbud) Kabupaten Jepara, dan Balai Taman Nasional Karimunjawa (BTNK) selaku pelaksana kebijakan di daerah.

Disporapar Provinsi Jawa Tengah telah menyusunmasterplanKarimunjawa.DKP provinsi Jawa Tengah sedang menyusun rencana zonasi sesuai amanat UU No. 27 Tahun 2007. BTNK telah menyusun zonasi dan rencana kelola TNKJ. Disparbud Kabupaten Jepara dan Disporapar Provinsi Jawa Tengah telah melakukan promosi dan pengembangan kapasitas SDM pelaku wisata Karimunjawa. Namun permasalahan sampah, air bersih, kerusakan terumbu karang, dan perubahan sosial budaya masyarakat muncul sebagai dampak dari pengembangan pariwisata di Karimunjawa. Meskipun secara ekonomi, masyarakat Karimunjawa mendapatkan dampak positif dengan terbukanya lapangan kerja baru dan pendapatan yang meningkat. Oleh karenanya, pengembangan pariwisata di Karimunjawa belum dapat dikatakan berkelanjutan.

\section{Saran}

Dalam pengembangan pariwisata diperlukan satu perencanaan yang terintegrasi yang melibatkan berbagai sektor dan berbagai stakeholders. Karena dalam pengembangan pariwisata ada 4 hal yang harus dipenuhi yaitu atraksi, aksesibilitas, amenitas, dan ancillary services yang dalam pemenuhannya melibatkan berbagai sektor dan stakeholders. Dalam perencanaan terintegrasi tersebut berisikan tentang penataan ruangnya yang harus sesuai dengan Rencana Tata Ruang Wilayahnya, perhitungan daya dukungnya (daya dukung ekologis, daya dukung fisik, dan daya dukung sosial), studi AMDAL atau UKL/UPL nya, pemanfaatan sumber daya alam secara ramah lingkungan, serta peran dan tanggung jawab dari setiap stakeholders yang terlibat dalam pengembangan pariwisata.

Untuk destinasi wisata dengan keindahan alam sebagai daya tariknya, terutama untuk pulaupulau kecil dan kawasan konservasi, sebaiknya dikembangkan untuk wisata dengan peminatan khusus. Selain itu juga perlu ada penerapan pembatasan wisatawan (sistem kuota), karena mass tourism berdampak negatif bagi ekosistem kawasan. Kuota wisatawan didasarkan pada hasil penghitungan daya dukung suatu kawasan. Agar pendapatan dari pariwisata tidak menurun, maka yang mungkin dapat dilakukan adalah dengan menambah atraksi sehingga lama kunjungan wisata bertambah. 


\section{DAFTAR PUSTAKA}

\section{Jurnal}

Astuti, Marhanani Tri., Any Ariani Noor. (2016). "Daya Tarik Morotai Sebagai Destinasi Wisata Sejarah dan Bahari", Jurnal Kepariwisataan Indonesia. Vol. 11 No. 1 Juni 2016. ISSN 1907 9419. Hlm. 25-46.

Budianto, Prima Farid., Edi Susilo, Erlinda Indrayani. (2013). "Implementasi Pengembangan Pariwisata di Pulau-Pulau Kecil terhadap Masyarakat Pesisir Desa Linuhu (Kecamatan Likupang, Kabupaten Minahasa Utara, Provinsi Sulawesi Utara)". Jurnal ECSOFiM. Vol. 1 No. 1. Hlm. 1-10.

Limbong, Ferncius., Sugiono Soetomo. (2014). Dampak Perkembangan Pariwisata Terhadap Lingkungan Taman Nasional Karimunjawa". Jurnal Ruang. Vol. 2 No. 1. Hlm. 351-360.

Ramdani \& Ramdani. (2017). Konsep Umum Pelaksanaan Kebijakan Publik. Jurnal Publik Vol. 11. No. 1. Hlm. 1-12.

Supriyanto, Yakobus. (2003). Pengembangan Wilayah Pulau-Pulau Kecil Berbasis Pariwisata (Kasus Kabupaten Karimun). Alami. Vol. 8 No. 3 Tahun 2003. Hlm. 11-17.

Tamaratika, Fenilia., Arief Rosyidie. (2017). Inkorporasi Kearifan Lokal dalam Pengembangan Pariwisata di Lingkungan Pantai. Jurnal Sosioteknologi. Vol. 16 No. 1. April 2017. Hlm. 125-133.

\section{Buku}

Bengen, D.G. (2001). Ekosistem dan Sumber Daya Alam Pesisir dan Laut. Bogor: Pusat Kajian Sumber Daya Pesisir dan Lautan, Institut Pertanian Bogor.

BPS Kabupaten Jepara. (tt). Kecamatan Karimunjawa Dalam Angka 2017. Jepara: BPS Kabupaten Jepara.

BTNK. (2017). Statistik Karimunjawa 2016. Semarang: BTNK.

BTNK. (2018). Rencana Pengelolaan Jangka Panjang Taman Nasional Karimunjawa Tahun 2018 2027. Semarang: BTNK.

Emzir. (2016). Metodologi Penelitian Kualitatif: Analisis Data. Edisi 1 Cetakan ke-5. Jakarta: Rajawali Pers.
Garrod, B., JC. Wilson. (2003). Marine Ecotourism: Issues and Experiences, England: Channel View Publication.

Kementerian Pariwisata. (2018). Laporan Akuntabilitas Kinerja Kementerian Pariwisata Tahun 2017. Jakarta: Kementerian Pariwisata.

Kurniawati, Rina. (2013). Modul Pariwisata Berkelanjutan. tidak diterbitkan.

Nakamura, Robert T. \& Frank Smallwood. (1980). The Politics of Policy Implementation, New York: St. Martin Press.

Pemerintah Provinsi Jawa Tengah. (2016). Executive Summary Penyusunan Rencana Induk dan Rencana Detail Kawasan Strategis Pariwisata Nasional (KSPN) Karimunjawa dan Sekitarnya. Semarang: Dinas Kebudayaan dan Pariwisata Provinsi Jawa Tengah.

Sugiyono. (2017), Metodologi Penelitian Kuantitatif, Kualitatif, dan Kombinasi (Mixed Method). Bandung: Penerbit Alfabeta.

Suwena, I Ketut. (2010). Pariwisata Berkelanjutan dalam Pusaran Krisis Global. Denpasar: Penerbit Udayana University Press.

Tachjan. (2006). Implementasi Kebijakan Publik, Bandung: AIPI Bandung-Puslit KP2W Lemlit Unpad.

Wahab, Solichin Abdul. (2008). Analisis Kebijaksanaan: Dari Formulasi ke Implementasi Kebijaksanaan Negara. Jakarta: Bumi Aksara.

Widodo, Joko. (2010). Analisis Kebijakan Publik. Malang: Bayu Media.

\section{Tesis}

Johan, Yar. (2011). Pengembangan Wisata Bahari dalam Pengelolaan Sumber Daya Pulau-Pulau Kecil Berbasis Ekologi: Studi Kasus Pulau Sebesi Provinsi Lampung. Tesis. Pascasarjana Institut Pertanian Bogor. Bogor.

\section{Makalah}

Bengen, D.G. (2002). Coastal Resources and Ecosystems and its Integrated and Sustainable Management. Makalah disampaikan dalam kegiatan Marine Journalis Training Paper yang diselenggarakan WWF Wallacea Progam, Bali, 9 -11 April 2002. 
Dahuri, Rohmin., (1998). Pendekatan EkonomiEkologis Pembangunan Pulau-Pulau Kecil Berkelanjutan dalam Edyanto, dkk (Ed), Prosiding Seminar dan Lokakarya Pengelolaan Pulau-Pulau Kecil di Indonesia kerja sama Depdagri, Dir. Pengelolaan Sumber Daya Lahan dan Kawasan, TPSA, BPPT dan Coastal Resources Management Project, USAID, B32 - B42.

Ratman, Dadang Rizki., Deputi Bidang Pengembangan Destinasi dan Investasi Pariwisata Kementerian Pariwisata. (2016). Pembangunan Destinasi Pariwisata Prioritas 2016-2019, makalah disampaikan dalam Rapat Koordinasi Nasional Kementerian Pariwisata tentang Akselerasi Pembangunan Kepariwisataan Dalam Rangka Pencapaian Target 12 Juta Wisman dan 260 Juta Wisnus 2016, di Jakarta tanggal 27 Januari 2016.

\section{Internet}

Direktori Pulau-Pulau Kecil di Indonesia," http:// www.ppk-kp3k. kkp.go.id/direktori-pulau/ index. php/public_c/pulau_data diakses 4 April 2018.

Hingga Agustus, 660.000 Wisatawan Mancanegera Kunjungi Jawa Tengah". Kompas.com, 26 September 2018, https:// travel. kompas. com/read/2018/09/26/1112 $00027 /$ hingga-agustus - 660.000 wisatawan-mancanegara-kunjungi-jawatengah diakses 5 November 2018.

Kemenpar Targetkan Kontribusi 15\% pada 2019”, Tri Listiyarini, Minggu 10 September 2017, http://id.berita satu.com/ home/kemenpar-target kan-kontribusi-15pada-2019/165 070, diakses 2 April 2018.

Pesona Karimunjawa Dongkrak Kunjungan Turis Asing ke Jepara”, 26 April 2017, http://jateng.metrotv news.com/bisnis/ ob 3 B ox $5 \mathrm{~N}-$ pesona-karimunjawadongkrak-kunjungan-turis-asing-kejepara, diakses 7 September 2018.

\section{Dokumen}

Nota Kesepahaman Antara Kementerian Pariwisata dengan Kementerian Lingkungan Hidup dan Kehutanan tentang Percepatan Pengembangan Pariwisata di Kawasan Hutan Nomor: NK.6/KS.001/ MP/2015 dan Nomor: NK.10/MenLHKKSDAE/2015.

Peraturan Pemerintah Nomor 50 Tahun 2011 tentang Rencana Induk Pembangunan Kepariwisataan Nasional.

Peraturan Presiden Nomor 64 Tahun 2014 tentang Koordinasi Strategis Lintas Sektor Penyelenggaraan Kepariwisataan.

Perda Jateng No. 4 tahun 2014 tentang Rencana Zonasi Wilayah Pesisir dan Pulau-pulau kecil Prov Jateng 2014 -2034.

Perda Provinsi Jawa Tengah No. 5 Tahun 2014 tentang Rencana Pembangunan Jangka Menengah Daerah (RPJMD) Provinsi Jawa Tengah Tahun 2013 - 2018.

Permenbudpar No. Km.67/UM.001/MKP/2004 tentang Pedoman Umum Pengembangan Pariwisata di Pulau-Pulau Kecil.

UU No. 23 Tahun 2014 tentang Pemerintahan Daerah.

UU No. 27 Tahun 2007 tentang Pengelolaan Wilayah Pesisir dan Pulau-pulau Kecil (yang telah diubah dengan UU No. 1 Tahun 2014). 